\title{
Troska w czasach zarazy. Notatki z lockdownu w Brazylii
}

2020 r. jest rokiem szczególnym. Pandemia koronawirusa (COVID-19) opanowała większość świata. Kraje, zwłaszcza te zachodnie, bogate i białe, ogarnięte widmem kryzysu ekonomicznego, społecznego i zdrowotnego, na różne sposoby zaczęły kontrolować swoich obywateli - ich możliwości kontaktu z innymi, nauki, pracy, przemieszczania się. Wszystko to spowodowało, że musieliśmy się nauczyć nowych sposobów komunikowania z ludźmi, zmienić swoje codzienne przyzwyczajenia oraz „zostać w domu”. To „zostanie w domu” różne kraje realizują na różne sposoby, od całkowitego zamknięcia aż po "prawie normalne” funkcjonowanie. Notatki te zaczęłam pisać w połowie kwietnia 2020 r., teraz jest koniec maja - sytuacja wygląda bardzo dynamicznie. Kraje europejskie powoli wychodzą z lockdownu, zaczynają się otwierać gospodarka i szkoły, w Stanach Zjednoczonych i Ameryce Południowej jeszcze szczytu pandemii nie ma.

W tym tekście chciałabym się zastanowić, głównie bazując na własnych obserwacjach i nieregularnie prowadzonym swoistym dzienniku czasu zarazy, jak możemy obecnie rozumieć pojęcie troski. Co to znaczy, że o kogoś lub coś się troszczymy lub jesteśmy troskliwi? Czy dbanie o kogoś, opiekowanie się jest powiązane z niepokojem o tę osobę? Albo inną istotę czy jeszcze szerzej - Planetę? Czy troska jest stanem umysłu, cechą charakteru, czy praktyką? Nie będzie to tekst naukowy, a raczej garść luźnych refleksji popartych własnym doświadczeniem, obserwacjami i wiedzą zdobytą od migrantów z różnych miejsc na świecie.

Polskie słowa „troska”, „troszczyć się” są powiązane ze słowem „trzaskać” i być może w pierwotnym znaczeniu odnosiły się do odpadków lub opiłków będących efektem trzaskania lub obróbki metalu. Dawne wyrazy pokrewne "troskać” i „troskać się” oznaczają uczucia lęku i niepokoju (Boryś 2005; hasła: „troszczyć się” i „dbać”). Z kolei synonimiczne „dbać”, również o nie do końca jasnej etymologii, 
być może pierwotnie znaczyło „chodzić na palcach, czujnie, skradać się”. Oba słowa są w każdym razie bardzo dawne i niemal od początku związane były z uczuciem niepokoju o kogoś lub coś oraz czułości i zapewnienia poczucia bezpieczeństwa. Zresztą samo bezpieczeństwo łączy się semantycznie ze słowem „piecza”, co z kolei jest przestarzałym określeniem opieki. Opieka (protection) jest również podstawowym znaczeniem angielskiego care. Jak podaje Cambridge Dictionary, care to: "the process of protecting someone or something and providing what that person or thing needs"'. Stąd też mamy tak potrzebną obecnie służbę zdrowia, czyli healthcare. Brazylijczycy mówią cuidar - dbać, troszczyć się, opiekować się, starać się, aby komuś nie stało się coś złego (cuidado to „ostrożny” oraz „uwaga”). Słowo pochodzi od łacińskiego cogitare, czyli „myśleć”2.

Jestem antropolożką i lingwistką, interesuje mnie to, co i jak ludzie mówią oraz co i jak robią. Jak o pewnych sprawach opowiadają oraz co w różnych sytuacjach robią. Innymi słowy, chciałabym się dowiedzieć, co to znaczy, że ktoś się o kogoś / o coś troszczy i jak to robi w sytuacji, w której obecnie znalazł się świat - pandemicznego zagrożenia koronawirusem. A także: co to znaczy, gdy ktoś mówi, że się „troszczy”, tj. w jakich sytuacjach używa się retoryki troski i w jakim celu się to robi. Za inspirację teoretyczną posłuży mi pojęcie „troska na odległość” zdefiniowane przez Helenę Patzer na potrzeby jej badań wśród Filipińczyków mieszkających w Stanach Zjednoczonych $(2013,2015,2018)$. Autorka pokazuje, jak transnarodowe rodziny oraz transnarodowa organizacja pomocowa dbają o bliskich i swoją społeczność. Pisze, że troska organizuje działania migrantów: powodem ich emigracji jest troska o rodzinę, zapewnienie lepszej przyszłości bliskim. Ponadto Filipińczycy chętnie reprodukują autostereotyp szczególnie troskliwego narodu, dlatego często pracują w tzw. sektorze opieki, jako lekarze, pielęgniarki czy opiekunowie osób starszych (Patzer 2018: 112). Jeszcze wyraźniej troszczenie się o siebie nawzajem online widać w filmie Heleny Patzer Money tree (2013). Członkowie rodziny rozdzieleni tysiącami kilometrów spożywają „wspólnie” posiłki, rozmawiają o codziennych wydarzeniach, postępach dzieci w szkole i poczynionych wydatkach. Takie rozmowy są wprawdzie sposobem kontroli przez tych, którzy przysyłają pieniądze i paczki, jednak jest to również okazanie troski o bliskich, ich edukację i zdrowie (Patzer 2018: 120). Zresztą, jak słusznie zauważają Łukasz Krzyżowski i Loretta Baldassar (2020), od migrantów możemy się nauczyć, jak dbać o bliskich na odległość. Oni umieją żyć w oddaleniu fizycznym, ale nie społecznym, tworzyć i utrzymywać więzi z ludźmi w różnych miejscach na świecie. Nie jest dla nich niczym nowym spędzanie świąt online, wspólne posiłki rodzinne z komputerem ustawionym na stole, przesyłanie sobie paczek z jedzeniem i przekazów pieniężnych oraz organizowanie życia codziennego w kilku przestrzeniach jednocześnie (Bielenin-Lenczowska 2015).

\footnotetext{
${ }^{1}$ https://dictionary.cambridge.org/dictionary/english/care (dostęp: 12.05.2020).

2 https://michaelis.uol.com.br/moderno-portugues/busca/portugues-brasileiro/cuidar (dostęp: 18.05.2020).
} 
Mam wrażenie, że teraz wszyscy mówią o trosce, jednak rozumieją ją bardzo różnie, czasem wręcz sprzecznie. Bo czyż polscy politycy, wykorzystując przywilej władzy, nie twierdzą, że troszczą się o obywateli, zakazując im chodzić do lasu? Nie mówią wszak o foucaultowskiej wszechogarniającej kontroli i zarządzaniu strachem, ale o dbałości o zdrowie obywateli. Z kolei tu, w Brazylii, prezydent Jair Bolsonaro, który uważa, że pandemia koronawirusa jest przesadzona i że należy jak najszybciej powrócić do „normalności”, mówi o „trosce o gospodarkę”. Sądzi, że brazylijski naród prędzej umrze z głodu niż od wirusa, który jest zwykłą "grypką" (gripezinha), i na wszelki wypadek pozbywa się z rządu kolejnych ministrów zdrowia. Apeluje o uzbrojenie ludności i zapowiada walkę z gubernatorami stanów, którzy nie zgadzają się na jego metody walki z pandemią. Tymczasem media, zwłaszcza zagraniczne, alarmują o tragicznej sytuacji w Brazylii, zwłokach leżących na ulicy w dzielnicach biedy i braku miejsc w szpitalach. W Polsce, w trosce - jak się uważa - o studentów, zajęcia prowadzone są online. W Brazylii zajęć online na uniwersytecie nie ma, ponieważ mamy się troszczyć o tych, którzy nie mają warunków, by tak pracować i studiować. Samo pozostanie w domu dla wielu stało się przywilejem w odniesieniu do tych, którzy domów nie posiadają i nie mają możliwości fizycznej izolacji. Nie wszyscy też mogą pracować zdalnie. Jednocześnie ci, którzy w domach zostali, często zdani są na dzielenie małej przestrzeni z przemocowymi rodzicami lub partnerami.

"Zaraza” zastała mnie w południowej Brazylii, w pięknym nadmorskim mieście Florianopolis. Na szczęście rozpoczęła się tu nieco później niż w Europie, bo już po szczycie sezonu turystycznego. Mam przywilej bycia tą, która mogła „zostać w domu", a moje dzieci mają przywilej nauki zdalnej, który oferuje im prywatna szkoła. Tu znacznie szybciej niż w Polsce otwarto sklepy i usługi - w tym fryzjerskie i kosmetyczne oraz restauracje. Ulice już po tygodniu czy dwóch przestały świecić pustkami, maseczki również nie są w powszechnym użyciu (wielu zakłada je przed wejściem do sklepu i po wyjściu z niego zdejmuje). Obecnie w zasadzie nie działają tylko szkoły i transport publiczny.

Codzienność w zamknięciu to przede wszystkim lęk o siebie i bliskich, spojrzenie z niepokojem w przyszłość, ale także zbyt dużo lub zbyt mało czasu. Mam czas na gotowanie, ale nie na pisanie i czytanie w skupieniu. $Z$ trójką dzieci w wieku szkolnym i przedszkolnym doskwiera mi samotność albo przynajmniej brak innego towarzystwa niż najbliższa rodzina. Troszczę się zatem - online - o przyjaciól, z którymi mogę przez Internet wypić kieliszek wina i porozmawiać. Zresztą technologie wychodzą naprzeciw spotkaniom online - Facebook wprowadził pokoje do wideokonferencji na Messengerze, w których bez limitu czasu może „siedzieć i rozmawiać" do 50 osób, łącznie z tymi, którzy nie mają konta na żadnym z portali będących własnością Marka Zuckerberga: „Utrzymuj kontakty dzięki pokojom Messengera. Karolino, zdajemy sobie sprawę, jak istotne jest poczucie bliskości z ważnymi dla Ciebie osobami, gdy nie możesz spotkać się z nimi osobiście. 
Pokoje Messengera umożliwiają szybkie i łatwe spotkania wideo dla grup znajomych i rodziny. Mamy nadzieję, że pomogą Ci utrzymywać kontakty z innymi”.

Troskę o przyjaciół i rodzinę - tę, która została w Polsce - możemy okazywać tak jak inni migranci, a obecnie wszyscy, którzy z tą rodziną nie mieszkają: na odległość. Moja teściowa się śmieje, że teraz częściej się spotykamy, niż kiedy byliśmy w Polsce. Staramy się bowiem, tak samo jak to robią migranci, utrzymywać ten kontakt regularnie. Gdybyśmy byli w Polsce, też nie moglibyśmy rodziców i teściów odwiedzić - troską jest bowiem nie pojechać i nie zarazić. Jak to w Dzień Matki (obchodzony w Brazylii 10 maja) powiedział prefekt Florianopolis: „Jeśli kochasz swoją mamę, nie odwiedzaj jej dziś”. Jednocześnie „troska wymaga obecności" (cuidar requiere estar) - pisze na swoim blogu Diana Mata Codesal i zastanawia się, jak w czasie pandemii opiekować się bliskimi, jednocześnie pracując i dbając o dom ${ }^{3}$. W czasie pandemii nasiliła się bowiem współczesna neoliberalna presja na (samo)rozwój. Mamy troszczyć się już nie tylko o bliskich, ale również o naszą edukację, kondycję fizyczną, śledzić najnowszą literaturę czy filmy oraz uczestniczyć w niezliczonych kursach on-line. I, jak słusznie pisze Magdalena Okraska, „zaczynamy wierzyć, że wszyscy powtarzają koreański, kiszą kimchi, sprzątają w szafach metodą Marie Kondo i pracują nad mięśniami ramion (...) Oczywiście spacer po łące czy picie piwa na ławce w słońcu przed blokiem nie są już robieniem czegoś »dla siebie«, lecz wałkonieniem się, mitrężeniem czasu, pospolitym lenistwem" (Okraska 2020).

Pandemia koronawirusa spowodowała również, że coraz więcej ludzi zaczęło rozglądać się wokół siebie i dostrzegać innych potrzebujących, którzy być może znaleźli się w trudniejszej sytuacji. A może właśnie w takiej samej - zawiązują się więc grupy wsparcia i kooperatywy pomocowe: szycie maseczek, gotowanie, oferty pracy, oferty nieodpłatnych zajęć on-line, sprzedaż, wymiana czy oddawanie różnych rzeczy. Wymaga to zaufania. Na przykład na jednym z forów mieszkańców podwarszawskiego Sulejówka na FB znajduje się ogłoszenie o sprzedaży kwiatów w pobliskim gospodarstwie:

„TULIPANY! 25 szt. (paczka) po 20 zł. Pieniążki proszę wrzucać do skrzynki pocztowej lub dzwonić 501704 253".

$\mathrm{Na}$ innym forum jest zdjęcie powieszonych na płocie domu maseczek wielorazowych z informacją, że każdy, kto potrzebuje, może sobie zabrać. Pojawiają się również oferty pracy dla tych, którzy z powodu pandemii pracę stracili. Bardzo budujący, szeroko komentowany i udostępniany stał się post pewnej Ukrainki, która straciła pracę jako pani sprzątająca, a jej mąż otrzymuje obecnie mniej zleceń w branży budowlanej. Napisała ona (pisownia oryginalna):

Kochane sąsiedzi! Nie wiem jaki znalerżć słowa, żeby wyrazić moją wdzięczność za wszystko co wy dla nas zrobili. W ten dzień,kiedy napisałam do Mam z Wesołej,my już mielizmy

\footnotetext{
3 http://www.migrationist.com/wp/blog/ (dostęp: 20.05.2020).
} 
pieniądzy,żeby opłacić mieszkanie. Za kilku dni w naszym mieszkaniu były pełne kartony jedzenia,a jeszcze kilka dni póznej-pełne szafy odzeży dla nas tszech. A trzy dni tomu syn mieł laptopa. Chcę podziękować wszystkich razem i kłaniać się nisko każdemu osobno,za te co w tak trudnem czasie zwrociliście uwage na prostą rodzinę z Ukrainy

W jednym $z$ komentarzy pod postem pojawiła się również informacja, że zarówno ona, jak i jej mąż dostali już kilka zleceń pracy. Niestety, oczywiście, obecne były również - na szczęście nieliczne i bardzo krytykowane - komentarze w stylu: „Wracajcie, skąd przyjechaliście”. Online powstały również grupy wsparcia i pomocy, jak np. „Widzialna ręka/Visible Hand” na Facebooku, gdzie można zgłaszać się z prośbą o wszelką pomoc: od finansowej, przez oferty pracy, aż po prośbę o rozmowę czy wspólne, wirtualne spędzenie czasu.

W Brazylii zaufanie do nieznanych sobie ludzi jest nieporównywalnie mniejsze. Bardzo dużo mówi się o bezpieczeństwie i zabezpieczaniu się. W mediach słychać o konieczności zamykania domów, ostrzega przed złodziejami w środkach komunikacji miejskiej i na ulicy. Na popularnym portalu OLX zaleca się, aby nie umawiać się z kupującymi u siebie $\mathrm{w}$ domu, ale $\mathrm{w}$ miejscu neutralnym - pod sklepem czy na stacji benzynowej. I najlepiej być wtedy w towarzystwie innej osoby. Przedstawiciele klasy średniej i wyższej nie ufają również instytucjom - edukacji czy służby zdrowia, wybierając szkoły i pakiety prywatne. Nie jest też łatwo wynająć dom - bez znajomości lub opłacenia co najmniej kilku miesięcy wynajmu $\mathrm{z}$ góry jest to $\mathrm{w}$ zasadzie niemożliwe. Jednocześnie rozwinięte są różnego rodzaju instytucje pomocowe, zwłaszcza działające przy szkołach i kościołach. Centrum Pomocy Społecznej UFSC prowadzi mapowanie działań solidarnościowych i wsparcia dla najbardziej potrzebujących w stanie Santa Catarina. $Z$ prowadzonych przez nich badań wynika, że obecnie działań zarówno oddolnych, jak i odgórnych jest znacznie więcej ${ }^{4}$ Do niektórych można oczywiście znaleźć sporo zastrzeżeń natury etycznej związanych z hierarchiami społecznymi, ale - jak pisał Ignacy Dutkiewicz w odniesieniu do akcji pomocowych Dominiki Kulczyk - w tym przypadku „pecunia non olet” (Dutkiewicz 2020). Update z dnia 19.05.2020 - właśnie zauważyłam przy jednej z głównych ulic w Ingleses (dzielnica $\mathrm{w}$ północnej części Florianopolis) donice $\mathrm{z}$ roślinami oraz skarbonkę $\mathrm{z}$ informacją: „Tu zostaw pieniądze” oraz imieniem i numerem telefonu sprzedawcy. A jednak zaufanie działa!

Kolejną kwestią jest troska o edukację. Szkoły wprowadzają różnego rodzaju rozwiązania - od codziennych lekcji on-line dla uczniów, po wirtualne lekcje kilka razy w tygodniu, przez wysyłane przez nauczycieli zadania do samodzielnego wykonania w domu. Tak czy inaczej, powoduje to, że wszyscy - chcąc nie chcąc - przechodzą na swego rodzaju edukację domową, a ta wymaga umiejętności, wsparcia ze strony rodziców, no i odpowiedniego sprzętu. My musieliśmy doku-

\footnotetext{
mapeamento-de-acoes-solidarias-na-pandemia/ (dostęp: 23.05.2020).
}

https://noticias.ufsc.br/2020/05/nucleo-do-servico-social-da-ufsc-promove- 
pić dodatkowy komputer i spędzamy kilka godzin ze średnim synem na odrabianiu lekcji (a doświadczenie w edukacji domowej nie jest nam obce). Szkoła, do której chodzą dzieci, reklamuje się jako jedna z najlepszych w okolicy, bardzo szafując retoryką troski w odniesieniu do nauki i podejścia do dzieci oraz rodziców. Jednocześnie teraz, w czasie pandemii, okazała się jedną z nielicznych w mieście, która nie oferuje rodzicom żadnej zniżki czesnego i zwolniła z pracy wszystkich stażystów oraz niektórych wieloletnich pracowników. Zresztą, mimo że szkoła jest bardzo droga, nauczyciele i pracownicy administracji zarabiają niewiele. Troska, jak widać, okazywana jest jedynie w odniesieniu do nauki (pozycji w rankingach) oraz profitów szkoły, ale już niekoniecznie w stosunku do pracowników i rodziców.

W Brazylii gołym okiem widać nierówności społeczne i ekonomiczne, w tym $\mathrm{w}$ dostępie do edukacji. Publiczne szkoły stanowe i gminne niemal nie oferują zajęć zdalnych, bo jak zauważa sekretarz ds. edukacji stanu Santa Catarina, Natalino Uggioni, aż 42\% uczniów nie ma w domu komputerów, a 18\% nie ma dostępu do internetu ${ }^{5}$. Szkoły publiczne dopiero od niedawna zaczęły organizować jakiekolwiek nauczanie na odległość, a te dzieci i ci nauczyciele, którzy nie mają komputerów w domu, mogą skorzystać ze szkolnego sprzętu. Zresztą zdalna nauka i praca możliwe są dla tych, którzy nie tylko mają w domu komputer z podłączeniem do Internetu, ale w ogóle dysponują domem i przestrzenią, by przy tym komputerze spokojnie usiąść.

Uniwersytety rozwiązały tę kwestię różnorodnie: wprowadzając albo zawieszając edukację online. Moja uczelnia, Uniwersytet Federalny stanu Santa Catarina, zawiesiła wszystkie formy edukacji. „Nie jesteśmy w stanie zapewnić studentom tego samego poziomu kształcenia, który dałyby im zajęcia "na żywo «" - pisze w zarządzeniu rektor ${ }^{6}$. Od niedawna poszczególne wydziały starają się jakkolwiek przekazywać wiedzę, np. lingwistyka organizuje cotygodniowe „Lives” na Instagramie. Ponadto pracownicy akademiccy mają w większości kontrakty dydaktyczno-naukowe i niezależnie od okoliczności i warunków musimy publikować i starać się o granty. Diana Mata Codesal, hiszpańska antropolożka zajmująca się migracją, zaprosiła mnie do grupy wsparcia dla antropolożek „zamkniętych w domach". Na stronie NaNoWriMo próbujemy opisywać swoje zmagania z pisaniem, podczas gdy jednocześnie musimy zajmować się dziećmi lub starszymi rodzicami. W zaproszeniu Diana napisała:

This is a support group for us female scholars lockdown at home taking care of kids, parents and ourselves, who still want to try keep on with our writing. This is a safe space, inspired by feminist logics of care, where we take care of each other. This is not a group fuelled by competition but by support, care and understanding.

${ }^{5}$ https://www.sc.gov.br/noticias/temas/coronavirus/coronavirus-em-sc-governo-do-estado-estabelece-sistema-de-trabalho-para-atividades-escolares-nao-presenciais (dostęp: 12.05.2020).

${ }^{6}$ https://noticias.ufsc.br/2020/04/coronavirus-administracao-central-da-ufsc-prorrogasuspensao-de-todas-as-atividades-presenciais-ate-30-de-abril/ (dostęp: 12.05.2020). 
Nie udaje mi się korzystać z NaNoWriMo-wych liczników czasu i napisanych słów, zresztą zdecydowanie kontestuję taką presję produktywności zbyt silnie obecną w neoliberalnej akademii. Jednak krótkie wymiany zdań z innymi antropolożkami o tym, jak sobie radzą, co udało się im napisać, a co przeczytać, są bardzo wspierające. Grupa zresztą przeniosła się również na Facebooka (z czasem tam zajmując więcej przestrzeni), gdzie okazało się, że dzielimy się nie tylko tym, co i kiedy piszemy, ale również tym, co w ogóle robimy w czasie lockdownu. Okazało się, że niemal wszystkie chętnie oddajemy się gotowaniu i pielęgnowaniu roślin w ogrodzie lub na balkonie. Ja również mniej piszę, a więcej gotuję, piekę, łącznie ze skomplikowanymi i pracochłonnymi potrawami, oraz uprawiam warzywa i sadzę kwiaty. Oczywiście to wszystko nadal stawia mnie w pozycji bardzo uprzywilejowanej. Żebym mogła pielęgnować rośliny i gotować obiady, muszę mieć dom i czas. Mam możliwość bycia w domu, zdalnej pracy i zdalnych zakupów. Tę możliwość mam dzięki temu, że zatroszczył się o to ktoś inny - mąż czy partner, który opiekuje się w tym czasie dziećmi, oraz ci, którzy w domu zostać nie mogą: kurier, który dowozi zakupy, czy pani w sklepie, z którego mogę skorzystać. Troszcząc się o tych ludzi, staram się robić zakupy jak najrzadziej, nie kupować tego, co nie jest mi teraz potrzebne (żeby kurier nie musiał przyjeżdżać), chodzić w maseczce i unikać dużych skupisk ludzi.

Jako antropolodzy mamy jeszcze jedno zadanie związane z troską o innych: o naszych rozmówców, współuczestników badań. Pojęcie anthropology at home nabiera teraz nowego wymiaru - nie możemy nawet z tego domu wyjść, aby obserwować czy rozmawiać. W sklepach, na ulicach i na leśnych ścieżkach mijamy się w maseczkach i z zachowaniem odległości. Być może powinniśmy użyć teraz określenia anthropology from home? Z konieczności musimy wszyscy stać się ekspertami od badań w internecie, specami od analizy dyskursu i pisać autoetnograficzne pamiętniki z czasów COVID-19. Takich tekstów, dzienników, refleksji powstaje obecnie bardzo dużo, być może zbyt dużo i pod zbyt dużą presją produktywności. Czasopisma, wydawnictwa i instytucje grantowe prześcigają się w CfP i CfA na publikacje i badania o czasie z koronawirusem. A co w sytuacji, kiedy już rozpoczęliśmy badania i nie możemy ich kontynuować? Moi rozmówcy i moje rozmówczynie są niedaleko, zaledwie 6 godzin jazdy samochodem, ale przecież nie mogę ich odwiedzić. Nie wiem, czy odbędą się zaplanowane święta i festiwale, na które chciałam pojechać. W ogóle nie wiem, czy takie badania terenowe, jakie prowadzę od dwóch dekad, będą mogły się jeszcze kiedykolwiek odbyć. Być może należy zweryfikować metodę etnograficzną i zamiast siedzieć w namiocie w środku wioski, będziemy już tylko siedzieć przed ekranem monitora. Mam nadzieję, że nie, ale na pewno trzeba będzie dostosować obecne kodeksy etyczne i starą lekarską zasadę „Primum non nocere” rozszerzyć na troskę o zdrowie swoje i uczestników badań. W zorganizowanym przez World Council of Anthropological Associations webinarze „Fieldwork in an era of pandemia: digital (and other) alternatives" uczestnicy zastanawiali się, w jaki sposób obecnie możemy prowadzić badania etnograficzne online. 
Czy ze wszystkimi takie badania da się prowadzić? Co z badaniami wśród tych, którzy nie mają dostępu do nowoczesnych technologii lub są niepełnosprawni??

Jestem przyzwyczajona do utrzymywania kontaktów online z uczestnikami moich badań. Nadal co jakiś czas rozmawiam z muzułmanami z Macedonii, z którymi prowadziłam wywiady przed kilkoma laty. Facebook jest dla mnie narzędziem komunikacji i źródłem wiedzy (Bielenin-Lenczowska 2015: 50) w badaniach wśród potomków Polaków w Brazylii. Zresztą Facebook wyszedł naprzeciw użytkownikom i 17 kwietnia 2020 r. wprowadził nową „reakcję” przedstawiającą obejmowanie serca, czyli właśnie troskę:

Przeżywamy to razem nawet gdy jesteśmy daleko od siebie. Dodaliśmy nową reakcję, aby umożliwić okazywanie dodatkowego wsparcia w sytuacji, gdy wiele osób jest od siebie rozdzielonych. Mamy nadzieję, że pomoże to Tobie, Twojej rodzinie i znajomym poczuć się nieco bliżej siebie - Zespół Facebooka ${ }^{8}$.

Mogę zatem wysłać taką reakcję na wiadomość od kogoś, kto stracił pracę, zachorował lub o coś czy kogoś się martwi. Ponadto, w związku z powszechnością aplikacji WhatsApp w Brazylii za jej pomocą utrzymuję sporadyczny kontakt z większością osób. No właśnie: sporadyczny. Jest to zdawkowe zapytanie: „Co słychać? Czy jesteście zdrowi? Czy wszystko dobrze?”. Liczę na to, ale przecież wcale nie mam pewności, że będę mogła te pytania zadać tym ludziom za jakiś czas osobiście.

Tak jak większość z nas, organizacje migranckie i diasporyczne przeniosły swoją aktywność do internetu. Mam teraz możliwość obserwować to, jak działa na odległość polska diaspora w Brazylii. Nie mogąc się spotykać, stowarzyszenia i grupy folklorystyczne organizują próby online oraz proponują różne aktywności związane z działalnością organizacji, które mogą odbyć się bez spotkania twarzą w twarz. Przykładowo grupa folklorystyczna i powiązany z nią chór „Karolinka” z São Mateus do Sul nagrywają regularnie piosenki - każdy ze swojego domu. Tak powstał utwór Witaj majowa jutrzenko z okazji 3 maja (i wcześniej 2 maja: dnia Polonii) i nieco wcześniej Czerwone jabłuszko oraz legenda o lajkoniku wysłana w ramach akcji „Moje polskie serce” organizowanej przez Klub Literacki im. Władysława Reymonta z União da Vitoria. Projekt „Moje polskie serce” zaproponowany został przez historyka, Michela Kobelinskiego, i jest inicjatywą online skupiającą potomków Polaków w południowej Brazylii. Ma na celu „przypomnienie miejsc pamięci, których obecnie nie można odwiedzić oraz zebranie informacji na temat epidemii tyfusa, która miała miejsce w 1911 roku w miejscowości Cruz Machado oraz obecnej pandemii COVID-19"9. Co tydzień prezentowana jest inna inna aktywność - członkowie spotykają się na grupie whatsappowej i np. wysyłają

\footnotetext{
${ }^{7}$ https://www.youtube.com/watch?v=pYQqeVMFb90 (dostęp: 19.05.2020).

${ }^{8}$ https://www.spidersweb.pl/2020/04/nowe-reakcje-na-facebooku.html (dostęp: 12.05.2020).

${ }^{9}$ https://www.youtube.com/watch?v=ZaITN9TSzY4\&fbclid=IwAR1wJXww3rXHDiVEZ4u

${ }^{M}$ K8XQ8DGU0yOtpSqj42Fxe7cKcY6ON4SN9JTrhQI (dostęp: 22.05.2020).
} 
nagraną przez siebie piosenkę po polsku, zdjęcia lub filmy z prezentacji folklorystycznych czy - w czasie Wielkanocy - świątecznego stołu i święconki. W weekend 22-24 maja odbył się Pierwszy Festiwal Polskich Zespołów Folklorystycznych online ( $1^{\circ}$ Encontro On-line de Grupos Folclóricos Poloneses). W spotkaniu wzięło udział 16 zespołów z Brazylii, Argentyny i Polski, w tym znane mi z badań „Karolinka”, „Mazury” i „Kraków”10.

Żebym mogła ten tekst napisać, ktoś też musiał się o mnie zatroszczyć. Należy się im podziękowanie: mojemu mężowi, który w tym czasie zajmował się dziećmi, dzieciom (za to, że akurat spały albo robiły coś innego niż okupowanie mojego komputera), Magdzie - bo wysłała mi skany ze słowników etymologicznych, Miłce - za dołączenie mnie do grupy Klubu Literackiego im. Reymonta i Heli - za rozmowy i inspiracje.

\section{Bibliografia}

Baldassar L., Krzyżowski Ł.

Physical but not social distancing: what we can learn from migrants

https://livinglab.com.au/45482/?fbclid=IwAR3sNjnzW8GBXeFt_60Vr_q8kAtmj192yy_iyf7MiCNN_kGrRJ-pUeNnvjM (dostęp: 14.04.2020).

Bielenin-Lenczowska K.

2015 Spaghetti $z$ ajwarem. Translokalna codzienność muzulmanów w Macedonii i we Włoszech, Warszawa.

Boryś W.

2005 Słownik etymologiczny języka polskiego, Kraków.

Dudkiewicz I.

2020 Trzy uwagi o korona-dobroczynności. Ngo.pl. Portal organizacji pozarzadowych, https://publicystyka.ngo.pl/trzy-uwagi-o-korona-dobroczynnosci-felieton-dudkiewicza Okraska M.

2020 Joga czy zimne piwo?, „Popmoderna”, http://popmoderna.pl/joga-czy-zimne-piwo/?fbclid=IwAR1ct_a1 AvMSJG3cghLZgfPchVmdC8oG4Vm0Bdwk2HCi8PqJFJw0cVuPpvE (dostęp: 20.05.2020).

Patzer $\mathrm{H}$.

2018 Napotkanie przedtekstowego. Budowanie wiedzy etnograficznej o migranckich światach troski, „Teksty Drugie” nr 1, s. 111-126.

2015 Long-distance care. The practice of sustaining transnational ties by Filipino immigrants in Boston, praca doktorska, Warszawa, Uniwersytet Warszawski.

2013 Money tree, film etnograficzny, reż. Helena Patzer, zdj. Kacper Czubak. 40’ Polska.

${ }_{10}$ https://www.facebook.com/grupokarolinka/photos/pcb.4082293595121677/4082293295121 707/?type=3\&theater (dostęp: 20.05.2020). 